\title{
Temperature-dependent formation and photorepair of DNA damage induced by UV-B radiation in suspension-cultured tobacco cells
}

\author{
Shaoshan $\mathrm{Li}^{1}$, Markus Paulsson, Lars Olof Björn* \\ Department of Plant Physiology, Lund University, Box 117, SE-221 00 Lund, Sweden \\ *Corresponding author. Tel.: +46-46-222-7797; fax: +46-46-222-4113. E-mail lars olof.Björn@fysbot.lu.se (L.O. Björn). \\ ${ }^{1}$ Permanent address: Department of Biology, School of Life Sciences, South China Normal University, Guangzhou 510631, People's \\ Republic of China. E-mail addresse: lishsh@scnu.edu.cn,
}

\begin{abstract}
Two photoproducts of DNA damage, i.e. cyclobutane pyrimidine dimers (CPDs) and 6-4 photoproducts (6-4PPs), induced by UV-B radiation in suspension-cultured tobacco cells were quantified by enzymelinked immunosorbent assay (ELISA) with monoclonal antibodies. CPDs and 6-4PPs were induced in tobacco cells by UV-B radiation. Photorepair of CPDs was faster than that of 6-4PPs. UV-B radiation induces formation of CPDs and 6-4PPs even at $0^{\circ} \mathrm{C}$, but low temperature significantly decreases the UV-Binduced (in contrast to UV-C-induced) formation of CPDs and 6-4PPs. Low temperature also retarded the removal of CPDs and 6-4PPs under white light, and almost no photorepair of CPDs and 6-4PPs was detected at $0^{\circ} \mathrm{C}$. When purified DNA from tobacco cells grown in darkness was irradiated with UV-B, formation of CPDs and 6-4PPs took place at the same speed at different temperatures. It indicated that formation of CPDs and 6-4PPs induced by UV-B was temperature-independent in a non-cellular system. Based on our results for suspension-cultured tobacco cells, not only the photorepair but also UV-B-induced formation of CPDs and 6-4PPs are temperature-dependent. (C) 2002 Published by Elsevier Science B.V.
\end{abstract}

Keywords: Cyclobutane pyrimidine dimers; DNA damage; 6-4 Photoproducts; Photorepair; Temperature; Tobacco (Nicotiana tabacum); UV-B

\section{Introduction}

Ozone depletion in the stratosphere results in enhancement of UV-B $(280-315 \mathrm{~nm})$ radiation at the Earth's surface. This is known to have pronounced biological effects. Plants use sunlight for photosynthesis and, as a consequence, are exposed to solar UV-B radiation. Investigations during the last two decades prove that UV-B radiation damages various plant processes. Such damage can be classified into two categories: damage to DNA (which can cause heritable mutations) and damage to physiological processes [1]. The main class of UV-B-induced DNA lesions consists of dimeric pyrimidine photoproducts. The two most frequent types of DNA lesions induced by UV-B radiation are the cyclobutane pyrimidine dimers (CPDs) and pyrimidine (6-4) pyrimidone adducts, commonly referred to as (6-4) photoproducts (6-4PPs) [2]. They cause inhibition of DNA replication, and sometimes result in mutations. Repair of DNA damage to prevent the biological effects caused by UV-B radiation is essential for plants to survive. Both these lesions can be repaired by light-dependent enzymes called photolyases (a process called photorepair or photoreactivation). In photorepair, a single enzyme, photolyase, uses light energy in the range from 300 to $500 \mathrm{~nm}$ to reverse the dimerization of pyrimidines [2].

Although the existence of photorepair has been reported in many plants and the properties of plant photolyase were intensively investigated recently [2-4], information on the effects of environmental factors such as temperature on photorepair is limited. At high latitudes and elevations, temperature appears to be a 
major factor determining survival, growth, reproduction and thus geographic distribution of plants. Effects of temperature on DNA damage and repair may be critical for UV-B effects on plants in cold climates [5]. Literature on temperature dependence of enzymatic photorepair in eukaryotic organisms is scarce and there is a need for further experiments. In the present study, to estimate the temperature effects on DNA damage and photorepair, cell suspension cultures have been employed to avoid interference by other environmental and developmental factors.

\section{Materials and methods}

\subsection{Suspension culture of tobacco cells}

Suspension cultures of Nicotiana tabacum cells (Bright Yellow-2) were used for all experiments. The cells were cultured on 8-day subculture interval in modified Murashige and Skoog (MS) medium [6] consisting of $4.3 \mathrm{~g} / \mathrm{l} \mathrm{MS}$ salt mixture supplemented with $30 \mathrm{~g} / \mathrm{l}$ sucrose, $0.18 \mathrm{mg} / \mathrm{ml} \mathrm{KH}_{2} \mathrm{PO}_{4}, 0.1 \mathrm{mg} / \mathrm{ml}$ inositol, $1 \mathrm{mg} / \mathrm{ml}$ thiamine hydrochloride and $0.2 \mathrm{mg} / \mathrm{ml}$ 2,4-dichlorophen-oxyacetic acid as a growth hormone. The $\mathrm{pH}$ was adjusted to 5.8 with $1 \mathrm{M} \mathrm{KOH}$ prior to autoclaving. Suspension-cultured tobacco cells were grown in darkness at $24^{\circ} \mathrm{C}$.

\subsection{Light sources}

UV-B radiation, $1.74 \mathrm{~W} \mathrm{~m}^{-2}$ in the range $280-315 \mathrm{~nm}$ (containing also UV-A, $315-400 \mathrm{~nm}, 2.28$ $\mathrm{W} \mathrm{m}^{-2}$, but only $16 \mathrm{~mW}^{-2}$ below $280 \mathrm{~nm}$ ) was obtained from a $40 \mathrm{~W}$ Q-Panel UV313 lamp (Largo, Goteborg, Sweden) and filtered through $0.13 \mathrm{~mm}$ cellulose diacetate film. The radiation corresponds to $0.148 \mathrm{~W} \mathrm{~m}^{-2}$ at $300 \mathrm{~nm}$ as weighted by a DNA spectrum, Fig. 1 shows the spectral irradiance of the UV-B

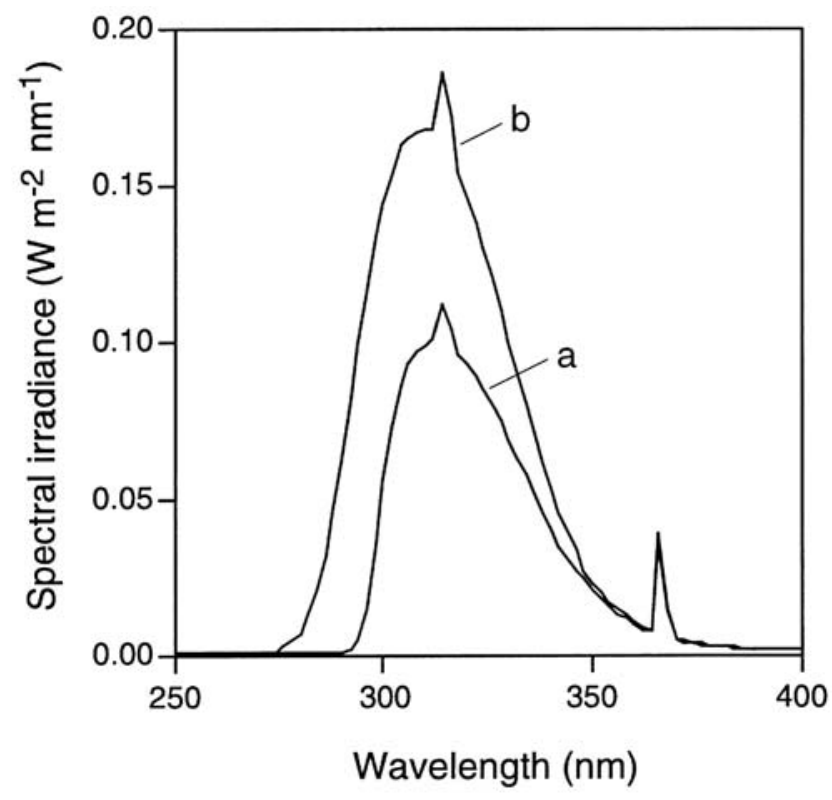

Fig. 1. Spectral irradiance of UV-B lamp with cellulose diacetate filter.

White light, $150 \mathrm{~W} \mathrm{~m}^{-2}$ in the interval $400-700 \mathrm{~nm}$, used for photorepair experiments, was supplied by a $400 \mathrm{~W}$ lamp (Osram Powerstar, HQI-T/ Germany) and filtered through a 10-cm depth of water in a transparent polystyrene container to remove excess infrared radiation. Fig. 2 shows the spectral irradiance of this white light. UV-C radiation was obtained from a low pressure mercury lamp with almost all emission, $4.39 \mathrm{~W} \mathrm{~m}$, concentrated to $254 \mathrm{~nm}$. This corresponds to about $175 \mathrm{~W} \mathrm{~m}^{-2}$ at $300 \mathrm{~nm}$ as weighted by a DNA spectrum. Radiation measurements were carried out with model 754 spectroradiometer 
(Optronic Laboratories, USA). Suspension cultured tobacco cells were irradiated in Petri dishes either with UV-B or UV-C at a distance of $20 \mathrm{~cm}$ from the lamp, and without any other illumination.

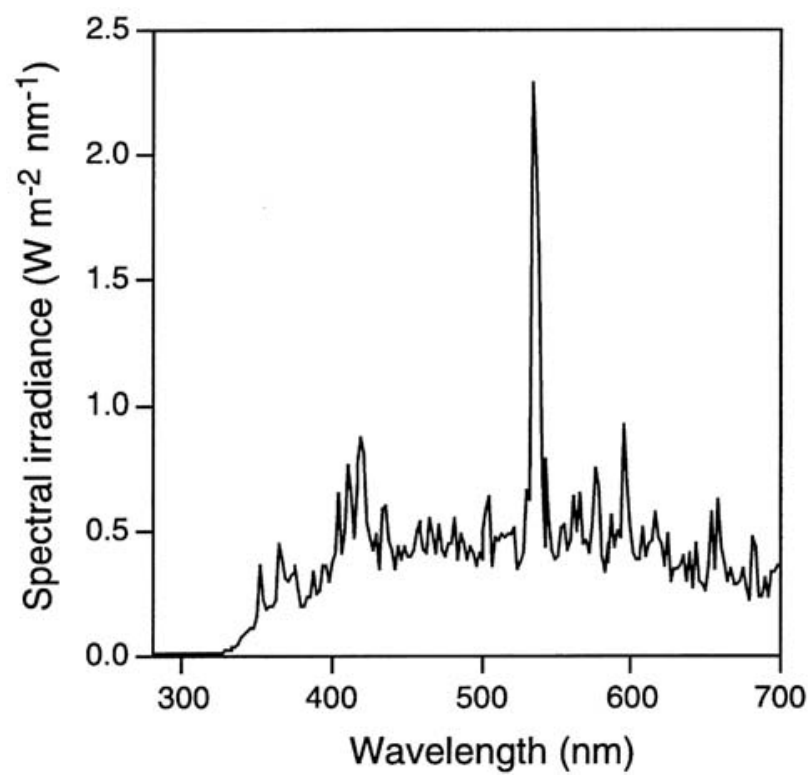

Fig. 2. Spectral irradiance of the white light.

\subsection{Temperature control}

The effect of temperature on the induction and photo-repair of DNA damage was tested at 0,12 , and $24^{\circ} \mathrm{C}$. Suspension cultured Nicotiana tabacum cells (BY-2) were pipetted into a small petri-dish without lid for exposure to radiation in a dark room. During exposure the petri-dish was thermostated and gently agitated. Tobacco cells were brought from the culture room $\left(24^{\circ} \mathrm{C}\right)$ to the experimental temperature in the dark room with 5-min temperature equilibration before exposure to radiation. Immediately after irradiation, the cells were harvested under dim yellow light for DNA extraction. Samples were taken in duplicate, and each temperature was tested in three independent experiments.

Purified DNA in $10 \mathrm{mM}$ phosphate buffered saline (PBS, pH 7.4) (50 ng/ ml DNA solution) from tobacco cells grown in darkness was pipetted onto Parafilm to form a drop, then exposed to UV-B radiation for $30 \mathrm{~min}$ at different temperatures. During UV-B radiation, the Parafilm was floating on the water bath which was connected to a circulation thermostat for temperature control. Immediately after UV-B radiation, drops of DNA solution were collected for DNA damage assay.

\subsection{Extraction of DNA}

Tobacco cells were separated from culture supernatant by a spin column sitting in a 2-ml collection tube which was centrifuged at $2500 \mathrm{x} g$ for $1 \mathrm{~min}$. Each sample (120 mg fresh weight) was frozen with liquid nitrogen in a sterile 1.5-ml Eppendorf tube, and homogenized with a small plastic pestel. DNeasy Plant Mini Kit (Qiagen $\mathrm{GmbH}$, Germany) was used to extract total DNA from the cells. All processing for DNA extraction took place under dim yellow light to avoid uncontrolled photorepair. The simple DNeasy spin column procedure yielded pure DNA in less than $1 \mathrm{~h}$ according to the protocol provided by Qiagen. The DNA extracted by the kit had $A_{260} / \mathrm{A}_{280}$ ratios of 1.7-1.9 and the absorbance scan showed a symmetric peak at $260 \mathrm{~nm}$, confirming high purity. The DNA concentration was determined by the absorbance at $260 \mathrm{~nm}$. Samples were either processed immediatedly or stored at $-20^{\circ} \mathrm{C}$. 


\subsection{Assay of DNA damage}

The CPDs and 6-4PPs were quantified by enzyme-linked immunosorbent assay (ELISA) according to Mori et al. [7] with monoclonal antibodies KTM53 and KTM50, respectively. Both antibodies were supplied commercially by Kamiya Biomedical Company, USA. The monoclonal antibody from clone KTM 53 specifically recognizes thymine dimers in double-or single-strand DNA produced by UV-radiation, but does not react with 6-4PPs. The monoconal antibody form clone KTM50 reacts specifically with 6-4PPs produced by UV-radiation, and does not react with thymine dimers. The detailed procedure was same as in our previous report [8]. Absorbance of the reaction mixture at $492 \mathrm{~nm}$ was measured with a microplate reader (Labsystems, Finland). For each case studied three complete experiments were carried out, and for each experiment the assay of DNA damage was carried out in triplicate. The standard errors reported are calculated on the means from each experiment.

\section{Results}

\subsection{CPDs and 6-4PPs induced by UV-B in cultured tobacco cells}

As shown in Fig. 3, photoproducts induced by UV-B in darkness were detected in suspension-cultured tobacco cells. Both types of DNA damage increased strongly with $1 \mathrm{~h} \mathrm{UV-B}$ exposure. After $1 \mathrm{~h}$, the increase of CPDs continued, but 6-4PPs began to decrease.

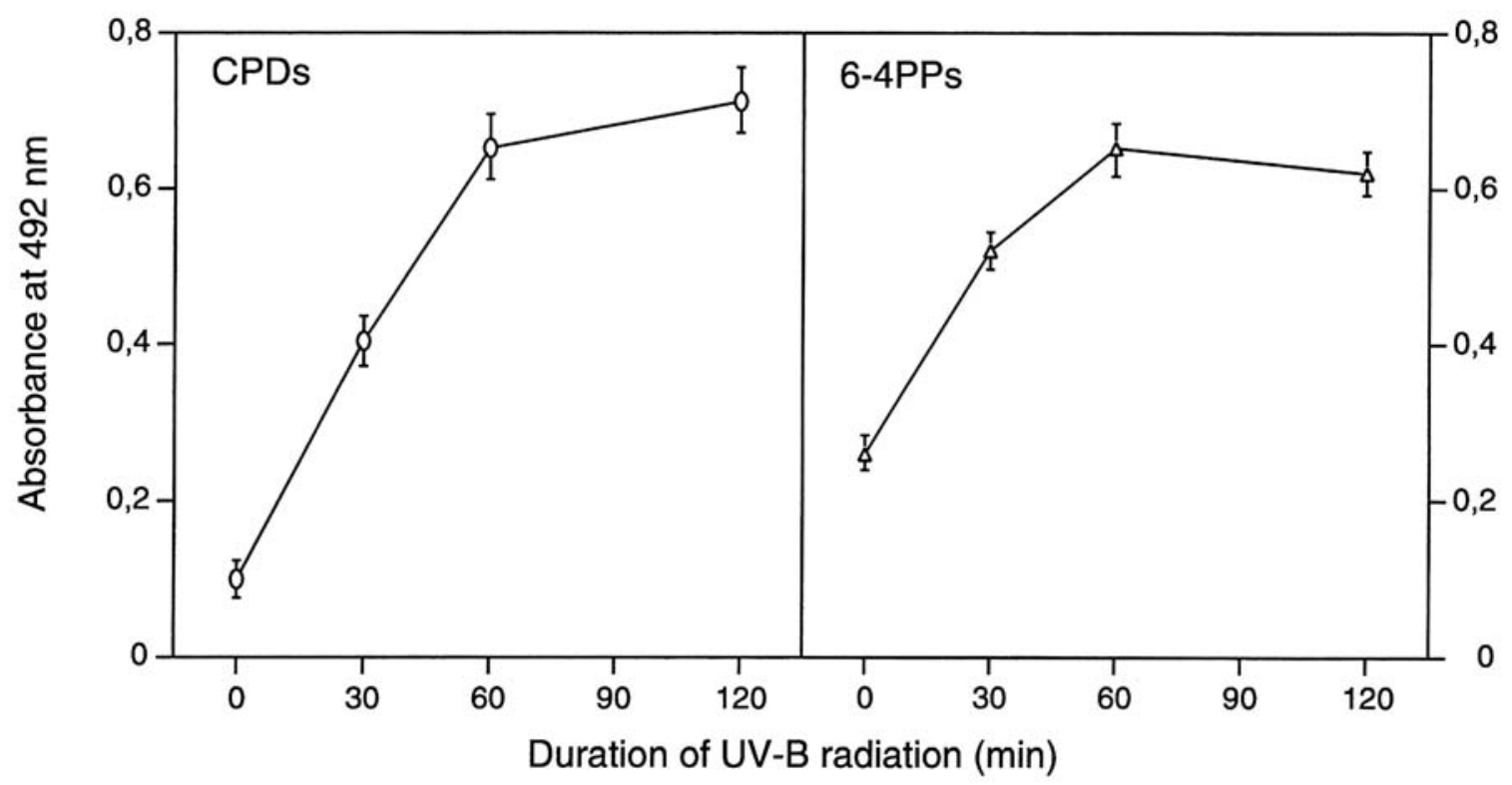

Fig. 3. UV-B induced formation of CPDs and 6-4PPs in tobacco cells. Cultured tobacco cells were irradiated with UV-B for indicated time at room temperature $\left(24^{\circ} \mathrm{C}\right)$. To each microplate well $50 \mathrm{ng}$ DNA were applied for ELISA assay of CPDs, and $100 \mathrm{ng}$ DNA for 6-4PPs detection. Absorbance at $492 \mathrm{~nm}$ was used as a measure of antibody binding. Average values are given with standard errors.

\subsection{Effect of temperature on the formation of CPDs and 6-4PPS}

It was found in our investigation that temperature has a great influence on the formation of UV-B- 
induced photoproducts in tobacco cells. After $1 \mathrm{~h}$ exposure to UV-B radiation, significantly less CPDs and 6-4PPs had formed at $0^{\circ} \mathrm{C}$ than at 12 and $24^{\circ} \mathrm{C}$ (Fig. 4). Accumulation of CPDs and 6-4PPs at $0^{\circ} \mathrm{C}$ was only 44.7 and $42.3 \%$ of that at $24^{\circ} \mathrm{C}$, respectively.

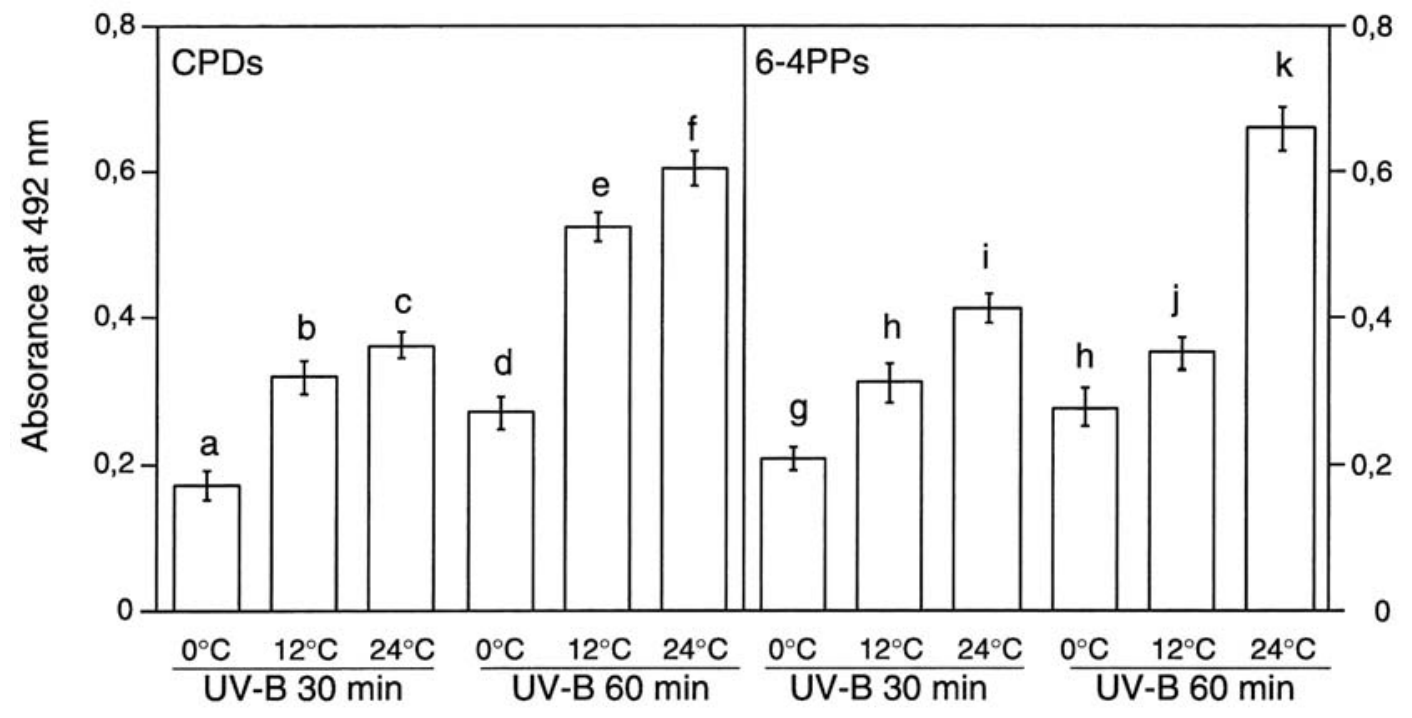

Fig. 4. Effect of temperature on UV-B-induced formation of CPDs and 6-4PPs in tobacco cells. Tobacco cells were exposed to UV-B radiation for 30 or $60 \mathrm{~min}$ in darkness. Different letters indicate significant difference at the $P, 0.05$ level in the $t$-test; otherwise as for Fig. 3 .

With 15 min UV-C irradiation, both types of DNA damage were strongly induced at all tested temperatures, and there were no significant differences in the amount of CPDs and 6-4PPs formed at 0,12 and $24^{\circ} \mathrm{C}$ (Fig. 5C).

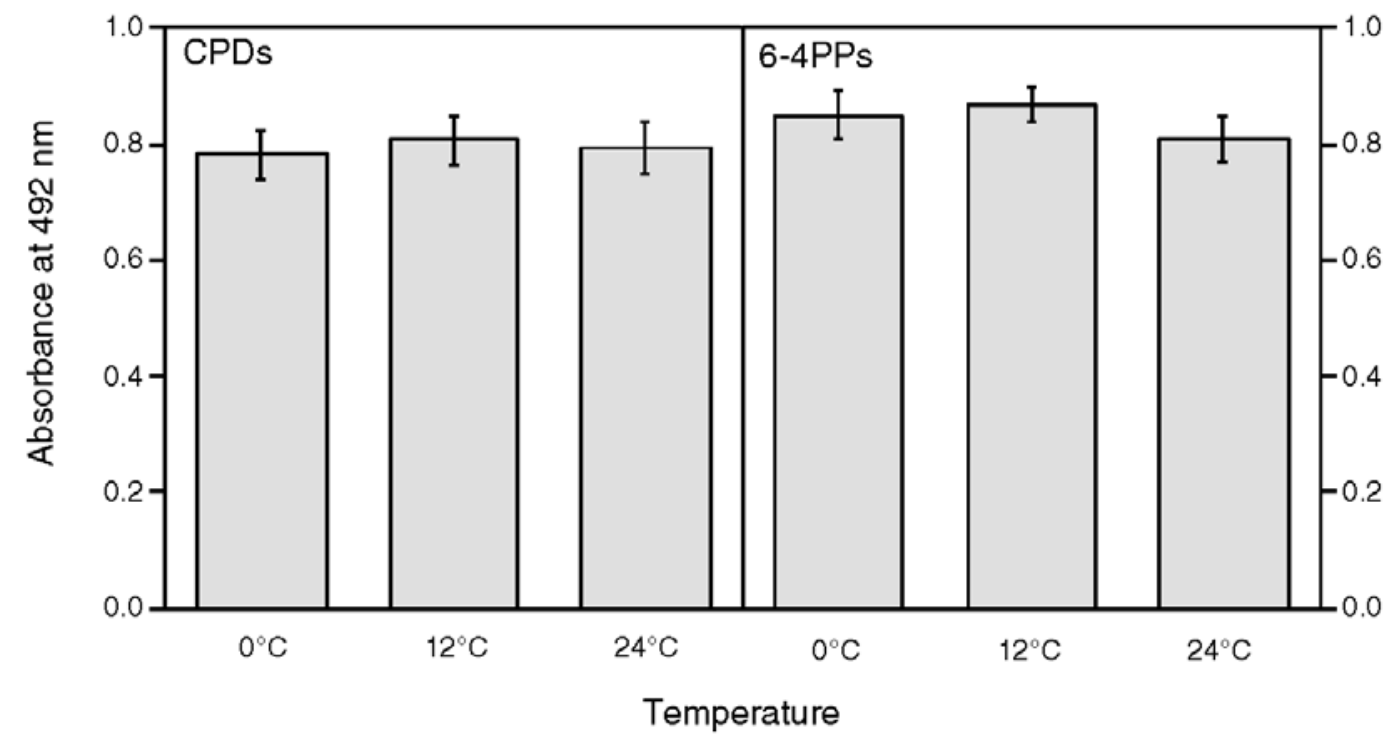

Fig. 5. DNA damages induced by UV-C radiation in cultured tobacco cells. Tobacco cells were exposed to UV-C radiation for $15 \mathrm{~min}$ at indicated temperatures under darkness. Immediately after radiation, tobacco cells were harvested for DNA extraction. Otherwise as for Fig. 3. 
When purified tobacco DNA (DNA solution) was irradiated with UV-B for $30 \mathrm{~min}$ in darkness, the same amounts of CPDs and 6-4PPs formed at 0,12 and $24^{\circ} \mathrm{C}$ (Fig. 6). It indicated that formation of CPDs and 64 PPs was a temperature-independent process in this non-cellular system.

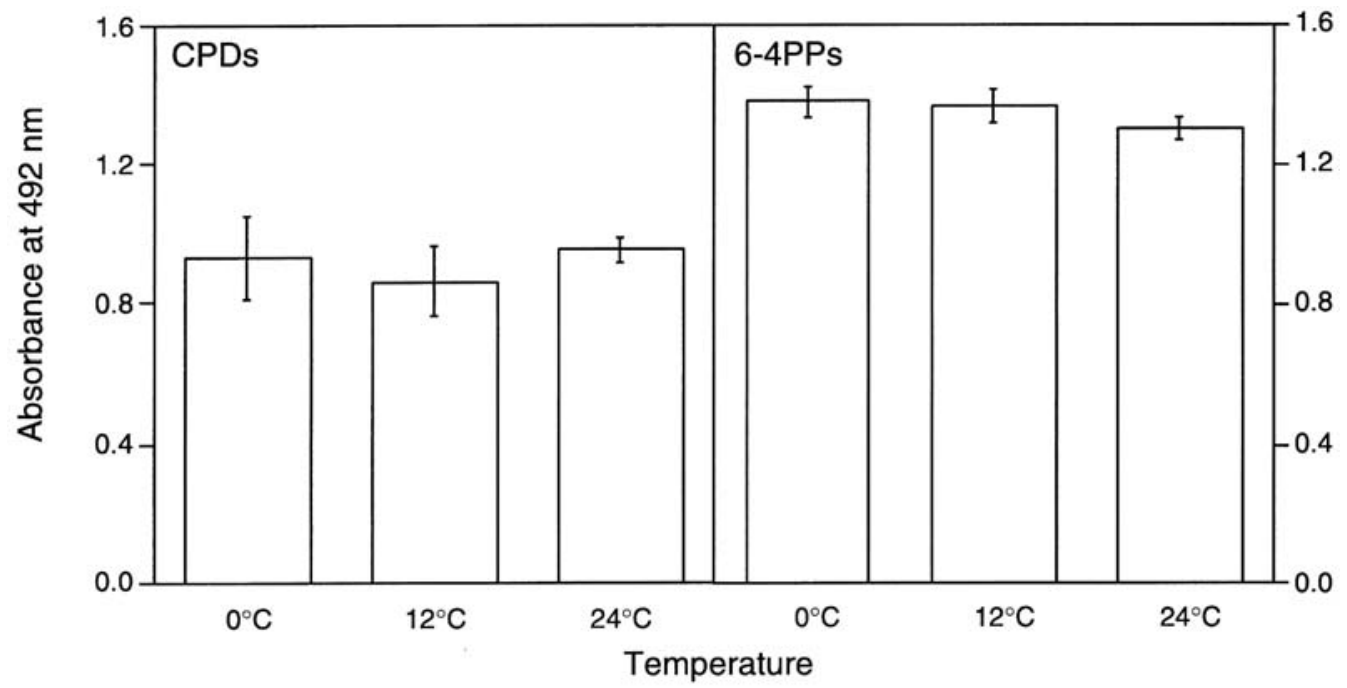

Fig. 6. Effect of temperature on the formation of photoproducts induced by UV-B radiation in DNA solution. Purified DNA in $10 \mathrm{mM}$ phosphate buffered saline (PBS, pH 7.4) $(30 \mathrm{ml}, 50 \mathrm{ng} / \mathrm{ml})$ from tobacco cells grown under darkness were exposed to UV-B radiation for $30 \mathrm{~min}$ at indicated temperatures under darkness. Otherwise as for Fig. 3.

\subsection{Effect of temperature on the photorepair of CPDs and 6-4PPs}

Photorepair of CPDs and 6-4PPs in tobacco cells at $24^{\circ} \mathrm{C}$ was more efficient than at 12 and $0{ }^{\circ} \mathrm{C}$. As shown in Fig. 7, 83.3\% of the CPDs were removed after $2 \mathrm{~h}$ of white light irradiation at $24^{\circ} \mathrm{C}$, and $71.9 \%$ removel at $12^{\circ} \mathrm{C}$. In the same time no significant removal of CPDs took place at $0^{\circ} \mathrm{C}$.

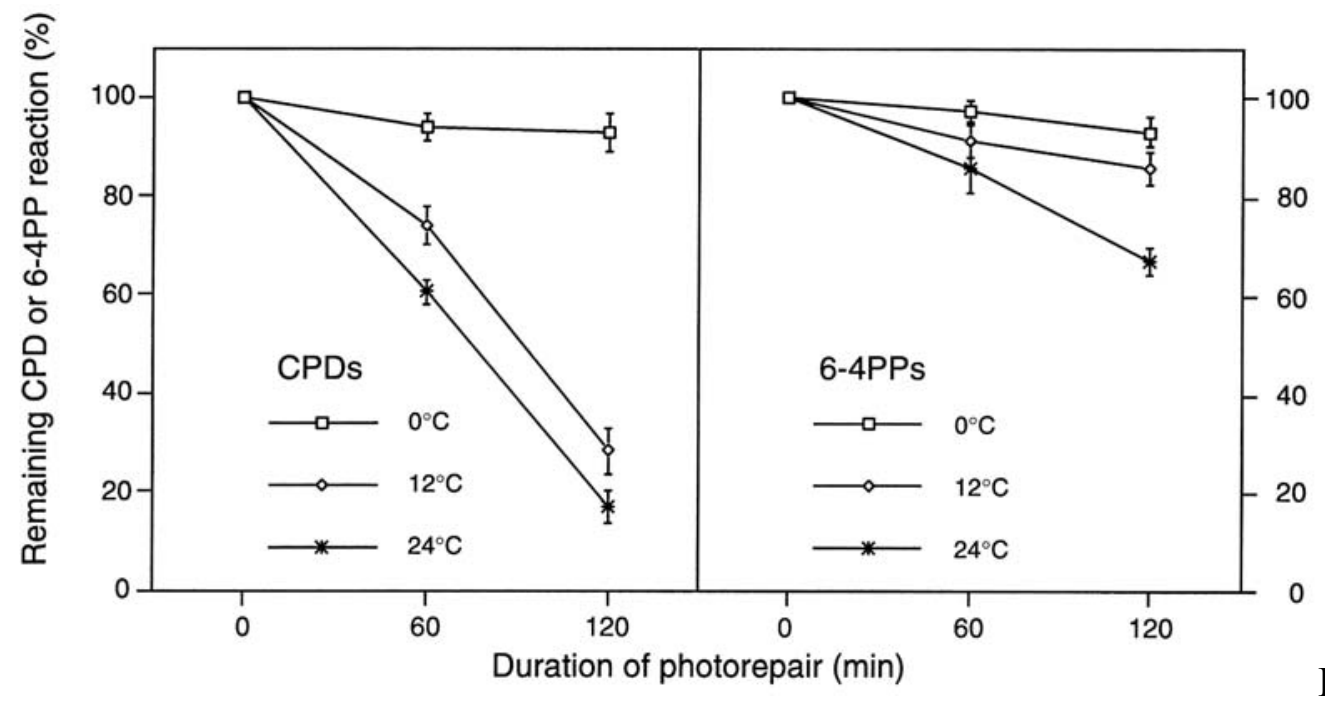

Effect of temperature on the photorepair of CPDs and 6-4PPs in tobacco cells. Tobacco cells were irradiated with UV-B for $1 \mathrm{~h}$ and subsequently irradiated with white light for indicated time at different temperatures. Otherwise as for Fig. 3. 


\section{Discussion}

As compared with photorepair of CPDs, removal of Most of the findings in the present investigation are in 6-4PPs under white light was much less efficient in line with what was anticipated. UV-B induced formation of cultured tobacco cells. With $2 \mathrm{~h}$ subsequent irradiation of CPDs and 6-4PPs in isolated DNA as well as UV-C white light at $24^{\circ} \mathrm{C}$, about one third (33.7\%) of 6-4PPs induced formation of these lesions in living tobacco cells were repaired. There was no significant photorepair of are temperature-independent processes, as expected for 6-4PPs at 0"C. purely photochemical reactions. Photorepair of the lesions is strongly temperature-dependent, as expected for enzymatic processes. These findings are also in line with previously published results, in particular those of Pakker et al. [9] and Takeuchi et al. [10], as well as results for banana from our laboratory (in preparation).

That the number of 6-4PPs decreases with the longest irradiation (Fig. 3) is probably due to conversion to Dewar isomers. These are formed under UV-A, and the radiation used has also a UV-A component.

UV-B induced formation of CPDs and 6-4PPs in living tobacco cells, contrary to our assumption, showed a temperature dependence, with less DNA damage at low temperature. However, also this is in line with previous findings by Takeuchi et al. [10].

Possible explanations for the temperature dependence in the latter case are:

1.The DNA is protected in vivo by its conformational state and its binding to protein. This protection may be temperature-dependent, and stabilizing forces more easily overcome at a higher temperature. It may also be that cell division and other DNA-requiring functions keep more of the DNA in an uncoiled, and therefore more vulnerable state at higher temperature. This explanation requires that the actions of UV-C and UV-B are somehow mechanistically different. Perhaps the more energetic UV-C photons are able to alter DNA independently of its state, while UV-B photons are more likely to excert their effect when DNA is in a vulnerable state.

2. While UV-C acts solely by direct absorption of photons by DNA and photochemical alteration of the electron orbitals, UV-B could possibly also act indirectly. This in turn could occur in two ways: (a) UV-B is absorbed by other substances, and hydroxyl radicals or other radicals or reactive oxygen species are generated which then attack DNA. Diffusion of such radiation products to the target, as well as their chemical reactions would be temperature-dependent. This explanation is not very likely. (b) A variant of this explanation is that the UV-B photon is absorbed by DNA, but with the initial process being a production of a radical site (unpaired electron) in the DNA at some distance from the pyrimidine base pair. The radical site would then migrate along the molecule in a temperature-dependent manner to the final target.

3. A third possibility is that UV-B photons, in addition to forming CPDs and 6-4PPs, are able to induce, in an indirect and temperature dependent manner, some other change in the DNA molecule, to which the antibodies also bind. We find this explanation unlikely, since we have used two different types of antibody, and they are both considered specific for their respective DNA lesions.

If temperature-dependence of the photorepair is a general phenomenon occuring also in plants adapted to cold environments, it could have important ecological implications. On high mountains a high UV-B fluence is combined with a low temperature. Cold temperatures also prevail at high latitudes, where the stratospheric ozone is depleted, and UV-B fluence rate is increased above natural levels, particularly in the spring. Under such circumstances UV-B can still induce CPDs and 6-4PPs, albeit at a lower rate, while the repair may be almost stopped by the low temperature. The balance between damage and repair would therefore be more unfavourable for the plant than in other environments.

\section{Acknowledgements}

This work was carried out under EC contract No. ENV4-CT97-0580. We are indebted to the European Commission for their support. Dr Shaoshan Li was supported in part by the Royal Swedish Academy of Sciences, and in part by the Natural Science Foundation of Guangdong, China. We thank Professor 
Susanne Widell for providing tobacco cell line BY-2, and Mrs Lena Carlsson for an introduction to cell culture techniques.

\section{References}

[1] A.E. Stapleton, Ultraviolet radiation and plants: burning questions, Plant Cell 4 (1992) 1353-1358.

[2] A.B. Britt, DNA damage and repair in plants, Annu. Rev. Plant Physiol. Plant Mol. Biol. 47 (1996) $75-100$.

[3] M. Hada, Y. Iida, Y. Takeuchi, Action spectra of DNA photolyases for photorepair of cyclobutane pyrimidine dimers in sorghum and cucumber, Plant Cell Physiol. 414 (2000) 644-648.

[4] M. Hada, G. Buchhola, T. Hashimoto, O. Nikaido, E. Wellmann, Photoregulation of DNA photolyases in Broom Sorghum seedlings, Photochem. Photobiol. 69 (1999) 681-685.

[5] L.O. Björn, T.V. Callaghan, C. Gehrke, U. Johanson, M. Sonesson, Ozone depletion, ultraviolet radiation and plant life, Chemosphere: Global Changes Sci. 1 (1999) 449-454.

[6] T. Murashige, F. Skoog, A revised medium for rapid growth and bioassay with tobacco tissue cultures, Physiol Plant. 15 (1962) 473-497.

[7] T. Mori, M. Nakane, T. Hattori, T. Matsunaga, M. Ihara, O. Nikaido, Simultaneous establishment of monoclonal antibodies specific for either cyclobutane pyrimidine dimer or (6-4) photoproduct from the same mouse immunized with ultraviolet-irradiated DNA, Photochem. Photobiol. 54 (1991) 225-232.

[8] S.S. Li, Y. Wang, X.J. Wang, J.H. Bin, S.H. Liu, Cyclobutane pyrimidine dimer accumulation in relation to UV-B sensitivity in rice cultivars, Acta Bot. Sin. 42 (2000) 576-581.

[9] H. Pakker, R. Martins, P. Boelen, A. Buma, O. Nikaido, A.M. Breeman, Effects of temperature on the photoreactivation of ultra-violet-B-induced DNA damage in Palmaria palmata (Rhodophyta), J. Phycol. 36 (2000) 334-341.

[10] Y. Takeuchi, M. Murakam, N. Nakajim, N. Kondo, O. Nikaido, Induction and repair of damage to DNA in cucumber cotyledons irradiated with UV-B, Plant Cell Physiol. 37 (1996) 181-187. 